\title{
Spectrophotometric Studies on the Thermodynamics of the ds-DNA Interaction with Irinotecan for a Better Understanding of Anticancer Drug-DNA Interactions
}

\author{
Reza Hajian ${ }^{1,2}$ and Tan Guan Huat ${ }^{2}$ \\ ${ }^{1}$ Young Researchers Club, Gachsaran Branch, Islamic Azad University, 75818-63876, Gachsaran, Iran \\ ${ }^{2}$ Department of Chemistry, Faculty of Science, University of Malaya, 50603 Kuala Lumpur, Malaysia \\ Correspondence should be addressed to Reza Hajian; hajian@iaug.ac.ir
}

Received 9 June 2012; Accepted 21 August 2012

Academic Editor: Lu Yang

Copyright ( 2013 R. Hajian and T. Guan Huat. This is an open access article distributed under the Creative Commons Attribution License, which permits unrestricted use, distribution, and reproduction in any medium, provided the original work is properly cited.

\begin{abstract}
The ds-DNA binding properties of irinotecan (CPT-11) including binding constant, thermodynamic parameter, and thermal denaturation $\left(T_{m}\right)$ have been systematically studied by spectrophotometric methods. The binding of CPT-11 to ds-DNA is quite strong as indicated by its remarkable hypochromicity and equilibrium binding constant $\left(K_{b}\right)$. The van't Hoff plot of $1 / T$ versus $\ln K_{b}$ suggests that the CPT-11 binds endothermically to ct-DNA which is characterized by large positive enthalpy and entropy changes. According to the polyelectrolyte theory, the charge release $(Z)$, when ct-DNA interacts with CPT-11, is +0.98 , which corresponds very well to the one positive charge carried by CPT-11. The $K_{b}$ at a low concentration of salt is dominated by electrostatic interaction (98.5\%) while that at a high concentration of salt is weakly controlled by nonelectrostatic processes (19.0\%). A moderate stabilization of the double helix ds-DNA occurs when CPT-11 binds to ds-DNA as indicated by the increase in $T_{m}$ of ct-DNA by approximately $15^{\circ} \mathrm{C}$ in the presence of CPT- 11 . The CPT-11 is stabilized by intercalation in the DNA (binding constant, $K$ [irinotecan-DNA $\left.]=5.8 \times 10^{4} \mathrm{~mol}^{-1} \mathrm{~L}\right)$ and displaces the NR dye from the NR-DNA complex $\left(K[\mathrm{NR}-\mathrm{DNA}]=2.7 \times 10^{4} \mathrm{~mol}{ }^{-1} \mathrm{~L}\right)$ in a competitive reaction.
\end{abstract}

\section{Introduction}

Irinotecan (CPT-11), a semisynthetic derivative of camptothecin, has a growing clinical impact due to its effectiveness in treating malignancies of the colon, lung, pancreas, cervix, and ovaries with increased survival benefits for patients. Irinotecan is converted in vivo to its much higher active metabolite, 7-ethyl-10-hydroxy camptothecin ( $\mathrm{SN}-38$ ) by carboxylesterases. Its disposition by the liver and bile is higher than by any other tissue. Irinotecan is characterized by its relatively poor and highly variable oral bioavailability and therefore this drug is mainly used for intravenous administration. Very few reports exist on irinotecan oral usage and hardly any attempts have been made to improve the oral bioavailability of irinotecan [1-5].

DNA plays a major role in the life process because it carries genetic information and instructs the biological synthesis of proteins and enzymes through the process of replication and transcription of genetic information. DNA is quite often the main cellular target for studies with smaller molecules of biological importance like carcinogens, steroids, and several classes of drugs. The investigation of drug-DNA interactions is of current general interest and importance [6-9], especially for the designing of new DNA-targeted drugs and the in vitro screening of these compounds. Early studies indicate that the mechanism of action for irinotecan involves inhibition of the mammalian DNA-topoisomerase-I, thereby causing stabilization of complexes during DNA replication, leading to cell death $[4,10]$. However, no reports based on evidence of direct interaction of CPT-11 with ds-DNA have been published. Irinotecan could destroy or have effects on the DNA destruction or transcription.

In this respect, our investigation provided a thermodynamic profile, standard free energy $\left(\Delta G^{\circ}\right)$, enthalpy $\left(\Delta H^{\circ}\right)$, and entropy $\left(\Delta S^{\circ}\right)$ changes of the DNA binding of CPT-11 using the van't Hoff plot by determining the equilibrium 
binding constant $\left(K_{b}\right)$ at various temperatures. These thermodynamic parameters allow us to further evaluate the enthalpic and entropic contributions to $\Delta G^{\circ}$ of the DNA binding of CPT-11. Moreover, the effect of salt concentration on the binding free energy of small molecules and DNA interactions has been long known. In general, the salt effect arises from the reorganization of the ionic cloud around the DNA and the binding ligand. The binding affinity of small molecules to DNA theoretically decreases when the salt concentration in the solution increases because ion-pair formation between binding ligand and DNA is less favorable in the solution that contains a high concentration of salt due to competition between cationic binding ligand and cationic metal ion released by the salt. However, a systematic study on the effect of salt concentration on the DNA binding of anticancer drugs is limited. The determination of the salt effect on the $K_{b}$ value of the DNA binding of drugs and then analyzing the results by the polyelectrolyte theory can be used to evaluate systematically the nonelectrostatic contribution to the $K_{b}$ and separate the total $\Delta G^{\circ}$ into its electrostatic and non-electrostatic contributions. Therefore, in the present study the salt dependence of the DNA binding of CPT-11 has also been characterized by determining its $K_{b}$ at various concentrations of salt $(\mathrm{KCl})$ using spectrophotometric titration. The data were then evaluated to determine the effects of electrostatic and non-electrostatic forces on the stabilization of the DNA-binding events of CPT-11.

In the current work, double stranded calf thymus DNA has been selected because of its low cost, ready availability, and ligand-binding properties. All the results of the study are consistent with the fact that calf thymus and human DNAs are homologous. Interactions with DNA could also be critical for understanding the drug toxicity and its distribution in the organism. The interaction of drug-DNA has been pursued vigorously in the field of life science, and clinical medicine resulting in many interesting studies $[11,12]$.

Neutral red (NR) is a planar phenazine dye and, in general, is structurally similar to other planar dyes, for example, those of the acridine, thiazine, and xanthene varieties. In recent years, the interaction of the fluorescent NR dye with DNA has been demonstrated by spectrophotometric [13-15] and electrochemical [16] techniques. In comparison with a common fluorimetric probe, ethidium bromide (EB) [17, 18], the NR dye offers lower toxicity, higher stability, and ease of use. In addition, its solution remains stable for up to 2 years $[19,20]$. In this work, NR was selected as the probe.

\section{Experimental}

2.1. Chemicals. Deoxyribonucleic acid sodium salt from calf thymus (Sigma Chem. Co., USA) was used without further purification, and its stock solution was prepared by dissolving an appropriate amount of DNA in doubly distilled water and stored at $4^{\circ} \mathrm{C}$. The concentration of DNA in stock solution was determined by UV absorption at $260 \mathrm{~nm}$ using a molar absorption coefficient $\varepsilon_{260}=6600 \mathrm{~L} \mathrm{~mol}^{-1} \mathrm{~cm}^{-1}$. Purity of the DNA was checked by monitoring the ratio of the absorbance at $260 \mathrm{~nm}$ to that at $280 \mathrm{~nm}$. The solution gave a ratio of $>1.8$ at $A_{260} / A_{280}$, which indicates that the DNA was sufficiently protein-free [13]. Irinotecan hydrochloride (CPT-11) stock solution $\left(1.0 \times 10^{-3} \mathrm{~mol} \mathrm{~L}^{-1}\right)$ was prepared by dissolving its powder (Sigma Chem. Co., USA) in deionized water and stored in a cool and dark place. Phosphate buffer $\left(20 \mathrm{mmol} \mathrm{L}^{-1}, \mathrm{pH} 7.5\right)$ and potassium chloride $(\mathrm{KCl})$ for adjusting the ionic strength were purchased from Fluka (USA). Neutral Red dye stock solution $\left(1.0 \times 10^{-3} \mathrm{~mol} \mathrm{~L}^{-1}\right)$ was prepared by dissolving its crystals (Sigma-Aldrich) in water and diluted to the required volume.

2.2. Spectrophotometric Measurements. The equilibrium binding constant $\left(K_{b}\right)$ for the ct-DNA binding of CPT-11 was determined by spectrophotometric titration at various temperatures and salt concentrations. A fixed amount of CPT-11 in $2.0 \mathrm{mmol} \mathrm{L}^{-1}$ phosphate buffer at $\mathrm{pH} 7.5$ was titrated with increasing amounts of ds-DNA stock solutions at various temperatures, that is, $30,35,40$, and $45^{\circ} \mathrm{C}$ or at various salt concentrations, for example, 10, 20, 50, and $100 \mathrm{mmol} \mathrm{L}^{-1}$. The spectra in the wavelength range of 200-700 $\mathrm{nm}$ were recorded by using a Shimadzu model 1650 UV-Vis spectrophotometer equipped with a FISONS model HAAKE D1 cell-temperature controller. For the determination of $K_{b}$ at various salt concentrations, the cell compartments were thermostated at $25 \pm 0.1^{\circ} \mathrm{C}$ and for the determination of $K_{b}$ at various temperatures the salt concentration was kept constant at $10 \mathrm{mmol} \mathrm{L}^{-1}$.

\section{Results and Discussion}

3.1. Spectrophotometric Confirmation on the Interaction of $C P T-11$ with $d s-D N A$. UV visible spectrophotometry is the most common and convenient way to study the interaction between small molecules or rare earth complexes and nucleic acids. Molecules containing aromatic or phosphate chromophore groups can interact with the double helix structure of DNA; therefore, the interaction between them can be investigated according to changes in the absorption spectra before and after the reaction.

The red shift (or blue shift), hyperchromic (or hypochromic) effects, and the isochromatic point are spectral properties of DNA-drug interaction, which are closely related with the double helix structure [21]. The hypochromicity at the maximum absorption of DNA $(260 \mathrm{~nm})$ is indicating the compaction of DNA due to the electrostatic interaction. Intercalation induces the hyperchromicity at this wavelength [22].

In order to validate the interaction between CPT-11 and ds-DNA, the UV-Vis absorption spectra of CPT-11 in the presence of different concentrations of ct-DNA were measured (Figure 1). A remarkable decrease in the absorption intensity of CPT-11 at $368 \mathrm{~nm}$ followed by hyperchromic effect at $280 \mathrm{~nm}$ was especially for the solution with a lower ionic strength, that is, $4.0 \mathrm{mM}$. The degree of hypochromicity $(H$ in \%) increases with temperature. For example, the hypochromic effect of CPT-11 absorption spectra goes up from $10.06 \%$ to $12.84 \%$ by increasing the temperature from $30^{\circ} \mathrm{C}$ to $45^{\circ} \mathrm{C}$ in the solution containing $2 \mathrm{mM}$ phosphate 
TABLE 1: Some thermodynamic parameters for the CPT-11 binding to ds-DNA at various temperatures.

\begin{tabular}{lcccc}
\hline$T(\mathrm{~K})$ & $H^{*}(\%)$ & $K_{b}\left(\mathrm{~L} \mathrm{~mol}^{-1}\right)$ & $\Delta H^{0}\left(\mathrm{KJ} \mathrm{mol}^{-1}\right)$ & $\Delta S^{0}\left(\mathrm{KJ} \mathrm{mol}^{-1} \mathrm{~K}^{-1}\right)$ \\
\hline 303 & 10.07 & $5.77 \times 10^{3}$ & 241.08 \\
308 & 10.85 & $8.77 \times 10^{3}$ & \\
313 & 11.82 & $1.11 \times 10^{4}$ & \\
318 & 12.84 & $1.54 \times 10^{4}$ & \\
\hline
\end{tabular}

${ }^{*}$ Hypochromicity.

TABLE 2: Hypochromicity $(H)$, total equilibrium binding constant $\left(K_{b}\right)$, nonelectrostatic equilibrium binding constant $\left(K_{t}^{0}\right)$, and ratio of $K_{t}^{0}$ to $K_{b}$ at various salt concentrations.

\begin{tabular}{|c|c|c|c|c|}
\hline$\left[\mathrm{K}^{+}\right]\left(\mathrm{mol} \mathrm{L}^{-1}\right)$ & $H(\%)$ & $K_{b}\left(\mathrm{~L} \mathrm{~mol}^{-1}\right)$ & $K_{t}^{0}\left(\mathrm{~L} \mathrm{~mol}^{-1}\right)$ & $K_{t}^{0} / K_{b}(\%)$ \\
\hline 0.01 & 8.21 & $6.37 \times 10^{4}$ & $8.81 \times 10^{2}$ & 1.38 \\
\hline 0.02 & 7.24 & $3.06 \times 10^{4}$ & $8.90 \times 10^{2}$ & 2.91 \\
\hline 0.05 & 6.27 & $2.56 \times 10^{4}$ & $9.06 \times 10^{2}$ & 3.53 \\
\hline 0.10 & 5.74 & $4.90 \times 10^{3}$ & $9.22 \times 10^{2}$ & 18.81 \\
\hline
\end{tabular}

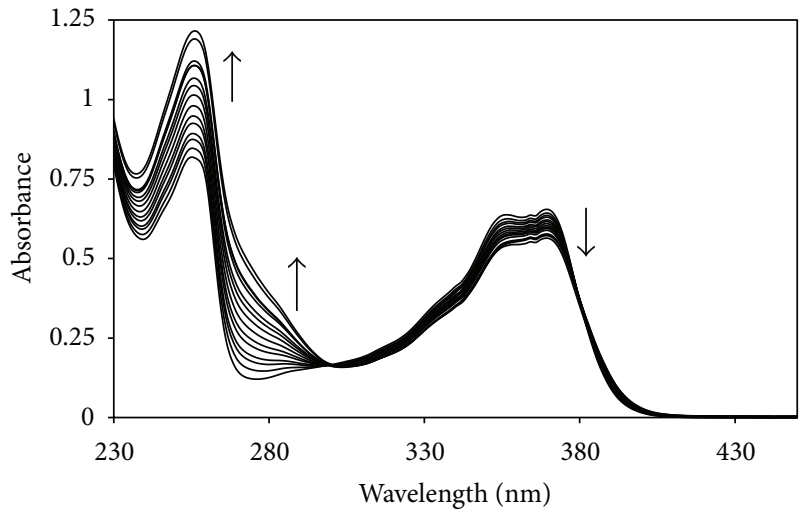

Figure 1: Absorption spectra of CPT-11 in the presence of dsDNA at different concentrations. $C_{\mathrm{DNA}}=0.0,6.1,12.2,17.9,23.8$, $29.5,35.2,40.8,46.3,51.8,57.2,62.5,67.8,73.0$, and $78.1 \mu \mathrm{mol} \cdot \mathrm{L}^{-1}$ for curves $1-15$, and $C_{\mathrm{CPT}-11}=30.0 \mu \mathrm{mol} \mathrm{L}^{-1}$ in phosphate buffer (0.002 $\left.\mathrm{mol} \mathrm{L}^{-1}, \mathrm{pH} 7.5\right)$.

buffer at pH 7.5 (Table 1). In contrast, the hypochromic effect of CPT-11 absorption spectra in the presence of DNA is found to decrease from $9.3 \%$ to $5.7 \%$ when the $\mathrm{KCl}$ concentration in the solution containing $2 \mathrm{mmol} \mathrm{L}^{-1}$ phosphate buffer ( $\mathrm{pH} 7.5)$ at $25^{\circ} \mathrm{C}$ is increased from $4 \mathrm{mmol} \mathrm{L}^{-1}$ to $100 \mathrm{mmol} \mathrm{L}^{-1}$ (Table 2).

Spectrophotometric titration curves measured in the wavelength region between 200 and $450 \mathrm{~nm}$ revealed that an isosbestic point is present at $296 \mathrm{~nm}$, indicating that there is an equilibrium state between CPT- 11 and ds-DNA. These remarkable hypochromic effects without a red shift indicate the existence of a strong interaction between CPT-11 and ds-DNA, most probably via the electrostatic mode of CPT11 within the ds-DNA double helix as well as intercalation especially at high ionic strength.

3.2. Thermodynamic Constants. In order to further investigate the interaction mode of CPT-11 with ds-DNA, the binding constant between drug-DNA at different temperatures and ionic strengths was calculated according to the doublereciprocal equation [23-25]:

$$
\frac{A_{0}}{A-A_{0}}=\frac{\varepsilon_{G}}{\varepsilon_{H-G}-\varepsilon_{G}}+\frac{\varepsilon_{G}}{\varepsilon_{H-G}-\varepsilon_{G}} \times \frac{1}{K_{b}[\mathrm{DNA}]},
$$

where " $A_{0}$ " and " $A$ " are the absorbances of CPT-11 in the absence and presence of DNA, respectively, and $\varepsilon_{G}$ and $\varepsilon_{H-G}$ are their extinction coefficients. The double reciprocal plots of $A_{0} /\left(A-A_{0}\right)$ versus $1 /[\mathrm{DNA}]$ were linear and the binding constants $\left(K_{b}\right)$ were calculated from the ratio of the intercept to the slope equations.

Although there have been many studies on the DNA binding of drugs to DNA, the measurements of thermodynamic parameters such as standard enthalpy $\left(\Delta H^{\circ}\right)$, entropy $\left(\Delta S^{\circ}\right)$, and free energy $\left(\Delta G^{\circ}\right)$ changes upon binding of drugs to ds-DNA have been exceptionally rare. In fact, the thermodynamic parameters of DNA-drug complex are essential for a thorough understanding of the driving forces governing the binding of drugs to DNA. To study the thermodynamic parameters of the ct-DNA binding of CPT-11, the binding constant of CPT-11 to ct-DNA has been determined at various temperatures, that is, $30,35,40$, and $45^{\circ} \mathrm{C}$ by spectrophotometric titration and the data were analyzed by (1). Typical reciprocal plots to determine the binding constant $\left(K_{b}\right)$ at different temperatures are shown in Figure 2 and the results of the $K_{b}$ determination are tabulated in Table 1. The values of the $K_{b}$ for the binding of CPT-11 with ds-DNA are nearly in accordance with the electrochemical method reported with Hajian and Huat [13]. The determination of the binding constants at various temperatures provides a good means to indirectly calculate the thermodynamic parameter of the DNA binding through the van't Hoff plot of $1 / T$ versus $\ln K_{b}$ in the corresponding temperature range (see Figure 3) [26-28]. Assuming that the enthalpy change $\left(\Delta H^{\circ}\right)$ is independent of temperature over the range of employed temperatures, $\Delta H^{\circ}$ of DNA-binding reaction of CPT-11 is immediately obtained from the van't Hoff plot (Table 1). The striking observation of this table is that CPT-11 binds endothermically to ds-DNA because the $K_{b}$ value increases with temperature. 


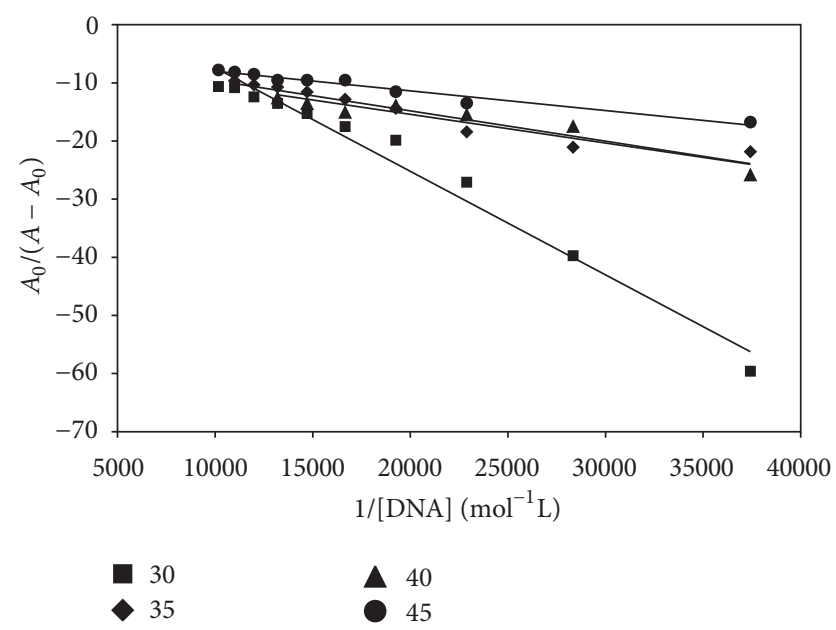

Figure 2: Typical plots of $A_{0} /\left(A-A_{0}\right)$ versus $1 /[$ ds-DNA] for the determination of the equilibrium binding constant $\left(K_{b}\right)$ based on (1) of the ds-DNA binding of CPT-11 at various temperatures.

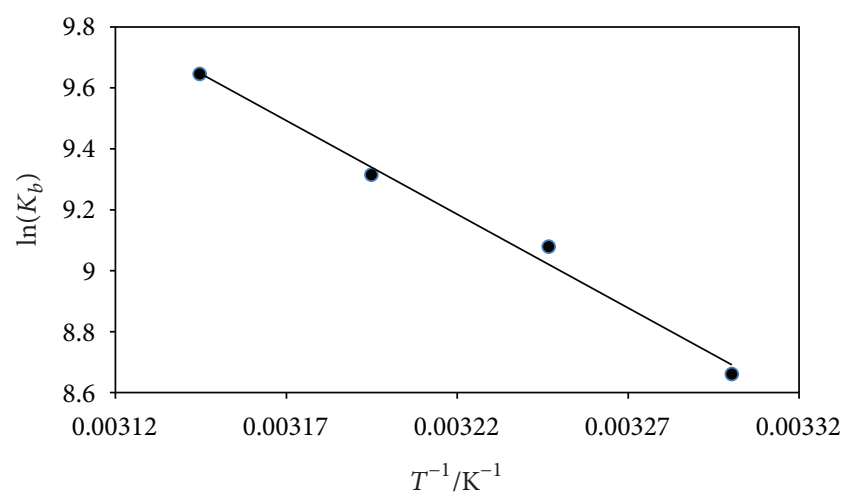

Figure 3: The van't Hoff plot of $\ln K_{b}$ versus $1 / T$ for the binding of CPT-11 to ds-DNA. All of conditions are similar to Figure 1.

3.3. Salt-Dependent Binding of CPT-11 to ds-DNA. By using the $3 \mathrm{D}$-Chem draw software on the total molecule charges, the results show that CPT-11 is a cationic molecule. Therefore it can be expected that its binding to DNA is thermodynamically linked to the amount of $\mathrm{K}^{+}$bound to DNA. As a result, the DNA binding constant $\left(K_{b}\right)$ of CPT-11 will depend on the total of $\mathrm{K}^{+}$concentration in the solution. In order to investigate such effect, we have determined the $K_{b}$ of the DNA binding of CPT-11 at various concentrations of $\mathrm{KCl}$ by means of spectrophotometric titration and the results are tabulated in Table 2. The binding constants reported here were obtained over the concentration range $0.010-0.100 \mathrm{~mol} \mathrm{~L}^{-1}$ $\mathrm{KCl}$ in order to apply the polyelectrolyte theory to calculate the nonelectrostatic binding constants and separate the total change in binding free energy into its electrostatic and non-electrostatic contributions. The salt concentrations of $0.010-0.100 \mathrm{~mol} \mathrm{~L}^{-1}$ were selected in this study because the polyelectrolyte theories used for subsequent analysis are based on limiting laws that are strictly applicable to salt concentrations lower than $0.100 \mathrm{~mol} \mathrm{~L}^{-1}$. It has been reported that the dependence of $K_{b}$ on salt concentration becomes nonlinear at higher concentrations of salt [29]. The plot of

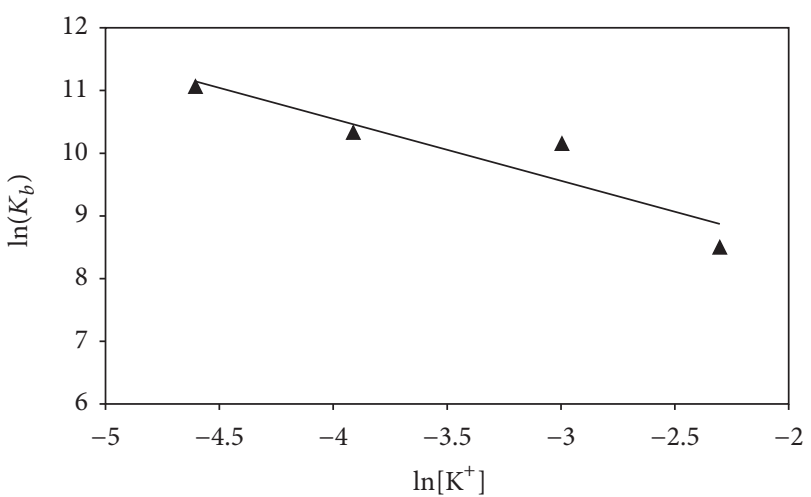

FIgURE 4: The effect of $\left[\mathrm{K}^{+}\right]$on the equilibrium binding constant $\left(K_{b}\right)$ for the binding of CPT-11 to ds-DNA.

$\ln \left[\mathrm{K}^{+}\right]$against $\ln K_{b}$ for the binding of CPT-11 to ds-DNA is shown in Figure 4. It is clear that the binding constant decreases by increasing the salt concentration. This is due to the stoichiometric amount of counter ion release that follows the binding of the cationic molecule [30], suggesting that electrostatic interactions are also involved in the DNA binding event. Using the slope from the linear fitting of Figure 4 , the non-electrostatic binding constant $\left(K_{t}^{0}\right)$ at various concentrations of $\mathrm{KCl}\left(\left[\mathrm{M}^{+}\right]\right)$can be calculated according to the following polyelectrolyte theory $[30,31]$ :

$$
\ln K_{b}=\ln K_{t}^{0}+Z \xi^{-1}\{\ln (\gamma \pm \delta)\}+Z \psi\left(\ln \left[\mathrm{M}^{+}\right]\right)
$$

where $Z$ is estimated from the slope of the regression line in Figure 4. $Z$ is the partial charge on the binding ligand involved in the DNA interaction as predicted by polyelectrolyte theory, $\psi$ is the fraction of counterions associated with each DNA phosphate $(\psi=0.88$ for double-stranded B form DNA), $\gamma_{ \pm}$is the mean activity coefficient for $\mathrm{M}^{+}$, and the remaining terms are constants for the double-stranded DNA in the $\mathrm{B}$ form, that is, $\zeta=4.2$ and $\delta=0.56$. The results of the calculations are summarized in Table 2 along with the percentage of non-electrostatic binding constant $\left(K_{t}^{0}\right)$ contribution to the total binding constants $\left(K_{b}\right)$ at various concentrations of $\mathrm{K}^{+}$. These $K_{t}^{0}$ can be taken as a measure of how large the non-electrostatic forces can stabilize the ligandDNA interaction. In contrast to the $K_{b}$ values which are salt dependent, the magnitude of $K_{t}^{0}$ is constant throughout the concentration of $\mathrm{KCl}$ employed with the average value of $7.37 \pm 0.99\left(\times 10^{3}\right) \mathrm{mol}^{-1} \mathrm{~L}$. This is consistent with the expectation for the salt independency of this parameter. Although the values of $K_{t}^{0}$ are constant throughout the concentrations of salt, the percentage of $K_{t}^{0}$ contributions to the $K_{b}$ increases significantly and reaches a maximum of $97.6 \%$ at $\left[\mathrm{K}^{+}\right]=0.1 \mathrm{~mol} \mathrm{~L}^{-1}$.

Further analysis is also possible to dissect the standard binding free energy change $\left(\Delta G^{\circ}\right)$ for the binding of CPT-11 to ds-DNA into its electrostatic $\left(\Delta G_{p e}^{0}\right)$ and non-electrostatic $\left(\Delta G_{t}^{0}\right)$ contributions at a given concentration of $\mathrm{KCl}$ [31]. Table 3 summarizes the results of the calculation of energetics 
TABLE 3: The effect of salt concentration $(\mathrm{KCl})$ on free energy changes $\left(\Delta G^{0}, \Delta G_{p e}^{0}\right.$ and $\left.\Delta G_{t}^{0}\right)$.

\begin{tabular}{lcccc}
\hline$\left[\mathrm{K}^{+}\right]\left(\mathrm{mol} \mathrm{L}^{-1}\right)$ & $\Delta G^{0}\left(\mathrm{KJ} \mathrm{mol}^{-1}\right)$ & $\Delta G_{p e}^{0}\left(\mathrm{~kJ} \mathrm{~mol}^{-1}\right)$ & $\Delta G_{t}^{0}\left(\mathrm{~kJ} \mathrm{~mol}^{-1}\right)$ & $\Delta G_{t}^{0} / \Delta G^{0}(\%)$ \\
\hline 0.01 & -27.41 & -11.27 & -16.14 & 58.88 \\
0.02 & -25.59 & -9.57 & -16.02 & 62.59 \\
0.05 & -25.15 & -7.33 & -17.82 & 70.85 \\
0.10 & -21.05 & -5.64 & -15.42 & 73.23 \\
\hline
\end{tabular}

for the binding of CPT-11 to ds-DNA at various concentrations of salt. The total binding free energy changes listed in Table 3 were calculated based on the standard Gibbs relation:

$$
\Delta G^{0}=-R T \ln K_{b}
$$

where $R$ is the gas constant and $T$ is the temperature in Kelvin. The salt dependence of the binding constant (Figure 4) is defined as the slope, $S K$ :

$$
S K=\frac{\delta \ln K_{b}}{\delta \ln \left[\mathrm{K}^{+}\right]}=-Z \Psi .
$$

The quantity of $S K$ is equivalent to the number of counterions released upon binding of the molecule with net charge $Z$. Based on Figure 4 it is found that approximately 0.98 counterion is liberated from DNA polymer upon binding of CPT-11. Using this value, which is equal to $Z \psi(\psi=0.88)$, the charge on CPT-11 molecule $(Z)$ can then be calculated and the value of +0.47 is obtained. The SK value can also be used to calculate the polyelectrolyte standard free energy change $\left(\Delta G_{p e}^{0}\right)$ contribution to the overall free energy change $\left(\Delta G^{\circ}\right)$ at a given $\mathrm{KCl}$ concentration by the relation $[13,21-$ 34]:

$$
\Delta G_{p e}^{0}=(S K) R T \ln \left[\mathrm{K}^{+}\right]
$$

The difference between the Gibbs free energy changes $\left(\Delta G^{\circ}\right)$ and $\Delta G_{p e}^{0}$ is defined as the non-electrostatic free energy change $\left(\Delta G_{t}^{0}\right)$ :

$$
\Delta G_{t}^{0}=\Delta G^{0}-\Delta G_{p e}^{0} .
$$

It is clearly observed from Table 3 that the standard electrostatic DNA binding free energy change $\left(\Delta G_{p e}^{0}\right)$ of CPT11 as predicted by the electrolyte theory decreases with the increase in salt concentration. In contrast, the nonelectrostatic binding free energy change $\left(\Delta G_{t}^{0}\right)$ is not affected by salt concentration in the solution and remains constant at $-16.35 \pm 1.63 \mathrm{~kJ} \mathrm{~mol}^{-1}$ in the $\mathrm{KCl}$ concentrations 0.01 to $0.1 \mathrm{~mol} \mathrm{~L}^{-1}$. This value of non-electrostatic binding free energy contributes approximately $58.9 \%$ to total binding free energy change $\left(\Delta G^{\circ}\right)$ for the solution containing $0.004 \mathrm{~mol} \mathrm{~L}^{-1} \mathrm{~K}^{+}$and increases to $73.23 \%$ for solution with $0.1 \mathrm{~mol} \mathrm{~L}^{-1} \mathrm{~K}^{+}$, suggesting that the stabilization of the DNA binding event both at low and high concentrations of salt is clearly dominated by non-electrostatic processes.

3.4. Interaction of NR with ds-DNA by Spectrophotometric Titration. Figure 5 shows the absorption spectra of the NR with the addition of DNA. It can be seen that the

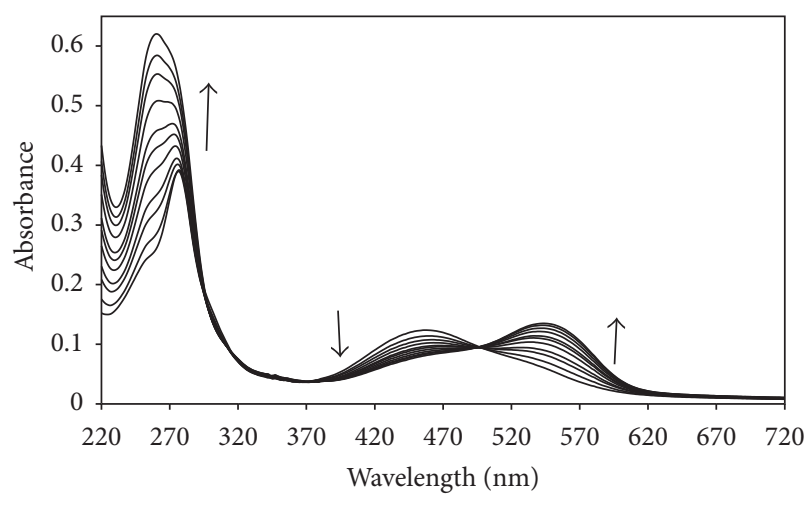

FIGURE 5: Absorption spectra for NR dye in the presence of dsDNA at different concentrations. $C_{\mathrm{DNA}}=0.0,6.7,13.4,20.1,26.8$, $33.5,40.2,46.9,53.6,60.3$, and $67.0 \mu \mathrm{mol} \mathrm{L}^{-1}$ for curves $1-11, C_{\mathrm{NR}}=$ $10.0 \mu \mathrm{mol} \mathrm{L}^{-1}$ in phosphate buffer $\left(0.002 \mathrm{~mol} \mathrm{~L}^{-1}, \mathrm{pH} 7.5\right)$.

absorption peak of the NR at approximately $455 \mathrm{~nm}$ exhibits a gradual decrease and a slight red shift with the increasing concentration of DNA, and a new band at about $545 \mathrm{~nm}$ appears. An isosbestic point at $490 \mathrm{~nm}$ provides evidence of the new DNA-NR complex formation. According to the double-reciprocal equation, the binding constant for NR binding to ds-DNA is calculated as $2.74 \times 10^{4} \mathrm{~mol}^{-1} \mathrm{~L}$. NR can intercalate into the base pairs of the double helix DNA uniquely [34], so it was employed as the molecule probe in the study.

3.5. Competitive Interaction of CPT-11 with the NR-DNA Complex. Further support for the mode of binding between CPT-11 and DNA is given through the competitive interaction of CPT-11 and NR with DNA. The observed band of DNA-NR complex at $531 \mathrm{~nm}$ gradually decreases in intensity with the increasing concentration of the added CPT- 11 . This band shifted slightly towards the blue end of the spectrum with the appearance of a new peak at $353 \mathrm{~nm}$, which increased progressively in intensity (Figure 6). This new band is the sum of the changing absorption of the NR dye $(531 \mathrm{~nm})$ and CPT-11 $(353 \mathrm{~nm})$. An isosbestic point at $414 \mathrm{~nm}$ provides evidence that a new species is formed during the competitive interaction and that the reaction is homogeneous. When compared with the absorption spectra of the NR dye in the absence or presence of DNA at $\mathrm{pH} 7.5$ (Figure 5), the results represented the reverse process. The observed changes in intensity and position of the bands with increasing concentration of CPT-11 added to the DNA-NR solution suggested that CPT-11 diffuses into the double helix of the DNA structure by substitution of NR in the DNA-NR system. 


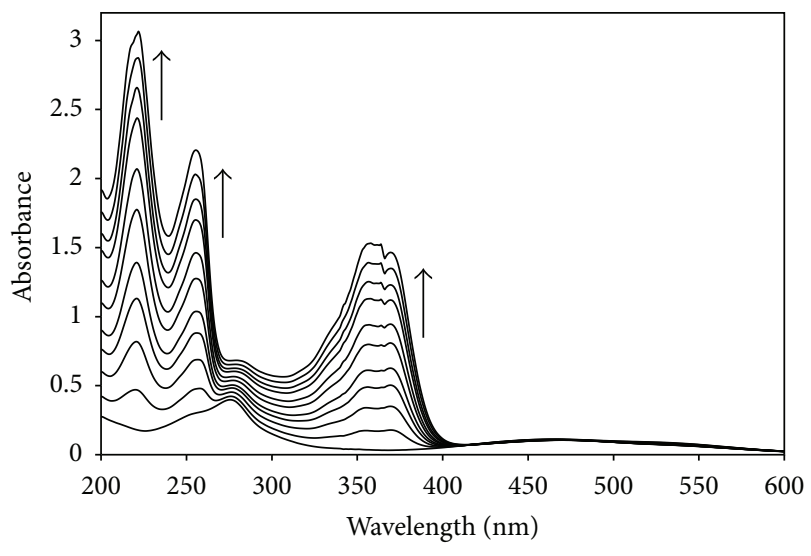

(a)

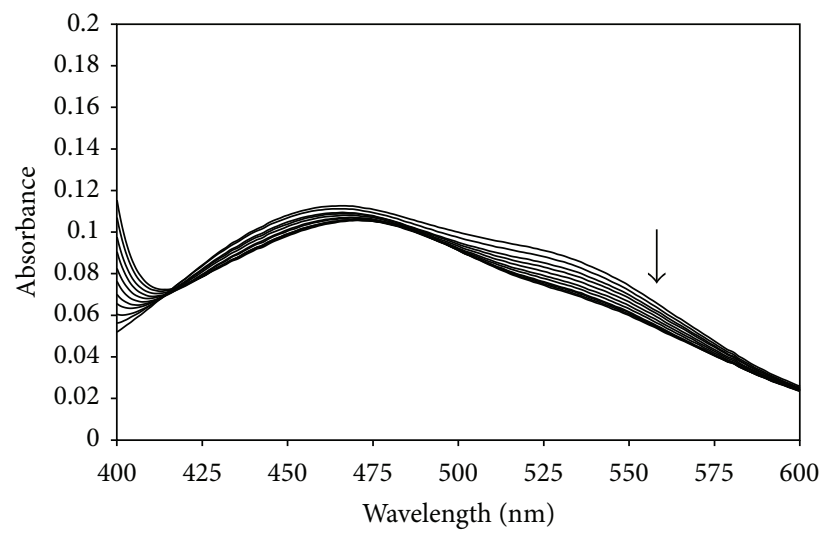

(b)

FIGURE 6: Absorption spectra of the competitive interaction between CPT-11 and NR bonded to ds-DNA in the wavelength ranges of (a) 220-600 nm and (b) 400-600 nm. Conditions: $C_{\mathrm{CPT}-11}=0.0,6.7,13.4,20.1,26.8,33.5,40.2,46.9,53.6,60.3$, and $67.0 \mu \mathrm{mol} \mathrm{L}{ }^{-1}$ for curves $1-11, C_{\mathrm{NR}}=10.0 \mu \mathrm{mol} \mathrm{L}^{-1}$, and $C_{\mathrm{NA}}=30.5 \mu \mathrm{mol} \mathrm{L}^{-1}$ in phosphate buffer $\left(0.002 \mathrm{~mol} \mathrm{~L}^{-1}, \mathrm{pH} 7.5\right)$.

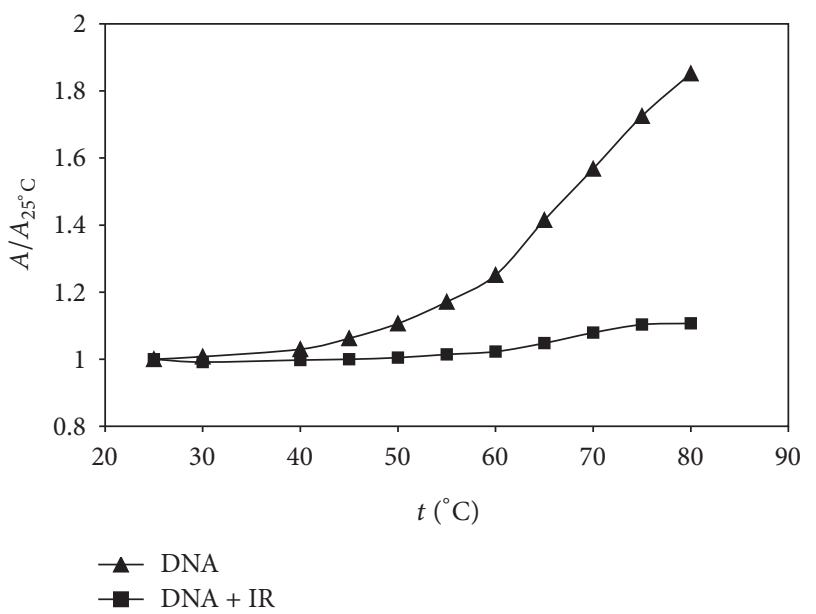

Figure 7: Thermal denaturation profile of ds-DNA in the absence and presence of CPT-11. Conditions: $C_{\mathrm{DNA}}=27.5 \mu \mathrm{mol} \mathrm{L}{ }^{-1}, C_{\mathrm{IR}}=$ $30.0 \mu \mathrm{mol} \mathrm{L}{ }^{-1}$, phosphate buffer $\left(0.002 \mathrm{~mol} \mathrm{~L}^{-1}, \mathrm{pH} 7.5\right)$.

These changes in the competitive interactions have been observed in several other studies [35].

3.6. Melting Studies. Heat and alkali can destroy the double helix structure of DNA and change it into a single helix at the melting temperature $\left(T_{m}\right)$. Interaction of small molecules with DNA can affect the $T_{m}$ value. Intercalation binding can stabilize the double helix structure and $T_{m}$ value increases above $5-8^{\circ} \mathrm{C}$, but the nonintercalation binding causes no obvious increase in $T_{m}[36,37]$. The values of $T_{m}$ for ds-DNA in the absence and presence of CPT-11 were determined, respectively, by monitoring the maximum absorbance values of the systems as a function of temperature ranging from $25^{\circ} \mathrm{C}$ to $80^{\circ} \mathrm{C}$. The melting curves are shown in Figure 7 . It can be seen that the $T_{m}$ value of ds DNA in the absence of CPT-11 is approximately $64^{\circ} \mathrm{C}$. The observed melting temperature of DNA in the presence of CPT- 11 is $67.0^{\circ} \mathrm{C}$. The interaction of CPT-11 with ds-DNA does not increase the $T_{m}$ value obviously, suggesting that intercalation binding is one of the minor mechanisms involved in the interaction of CPT-11 and ds-DNA.

\section{Conclusion}

It has been demonstrated that the binding of CPT-11 to ds-DNA is quite strong as indicated by the remarkable hypochromicity and equilibrium binding constant depending on the temperature and salt concentration in the medium. From the van't Hoff plot, it has been revealed that the CPT11 binds endothermically to ds-DNA, and therefore, its DNA binding is enthalpically driven as indicated by the large positive enthalpy and entropy changes. The salt dependence of the DNA binding of CPT-11 indicates that the charge release $(Z)$ when ds-DNA interacts with CPT-11 in accordance with the polyelectrolyte theory is +0.47 . The DNA binding constant of CPT-11 at a low concentration of salt $\left(0.01 \mathrm{~mol} \mathrm{~L}^{-1}\right)$ is dominated by electrostatic interaction (87.38\%) while that at a high concentration of salt is partially controlled by non-electrostatic processes $(97.57 \%)$. Nevertheless, the stabilization of the DNA binding in both cases is governed by electrostatic and non-electrostatic processes as reflected by the ratio of $\Delta G_{t}^{0} / \Delta G^{0}$ which are in the range of $58.88 \%$ (low salt) to $73.23 \%$ (high salt). A thermal denaturation study has suggested that the $T_{m}$ value of ds-DNA increased approximately by $3.0^{\circ} \mathrm{C}$ in the presence of CPT- 11 . The small value of $\Delta T_{m}$ suggests that irinotecan binds to ds-DNA by non-intercalation mode.

\section{Acknowledgment}

The authors gratefully acknowledge the support of this work by the University of Malaya.

\section{References}

[1] J. W. Jonker, J. W. Smit, R. F. Brinkhuis et al., "Role of breast cancer resistance protein in the bioavailability and fetal 
penetration of topotecan," Journal of the National Cancer Institute, vol. 92, no. 20, pp. 1651-1656, 2000.

[2] C. M. F. Kruijtzer, J. H. Beijnen, H. Rosing et al., "Increased oral bioavailability of topotecan in combination with the breast cancer resistance protein and P-glycoprotein inhibitor GF120918," Journal of Clinical Oncology, vol. 20, no. 13, pp. 2943-2950, 2002.

[3] J. M. Terwogt, M. M. Malingré, J. H. Beijnen et al., "Coadministration of oral cyclosporin A enables oral therapy with paclitaxel," Clinical Cancer Research, vol. 5, no. 11, pp. 3379-3384, 1999.

[4] C. F. Stewart, M. Leggas, J. D. Schuetz et al., "Gefitinib enhances the antitumor activity and oral bioavailability of irinotecan in mice," Cancer Research, vol. 64, no. 20, pp. 7491-7499, 2004.

[5] J. Van Asperen, O. Van Tellingen, A. Sparreboom et al., "Enhanced oval bioavailability of paclitaxel in mice treated with the P-glycoprotein blocker SDZ PSC 833," British Journal of Cancer, vol. 76, no. 9, pp. 1181-1183, 1997.

[6] B. K. Sahoo, K. S. Ghosh, R. Bera, and S. Dasgupta, "Studies on the interaction of diacetylcurcumin with calf thymus-DNA," Chemical Physics, vol. 351, no. 1-3, pp. 163-169, 2008.

[7] Y. Sun, S. Bi, D. Song, C. Qiao, D. Mu, and H. Zhang, "Study on the interaction mechanism between DNA and the main active components in Scutellaria baicalensis Georgi," Sensors and Actuators B, vol. 129, no. 2, pp. 799-810, 2008.

[8] X. Ling, W. Zhong, Q. Huang, and K. Ni, "Spectroscopic studies on the interaction of pazufloxacin with calf thymus DNA," Journal of Photochemistry and Photobiology B, vol. 93, no. 3, pp. 172-176, 2008.

[9] G. W. Zhang, J. B. Guo, J. H. Pan, X. Chen, and J. Wang, "Spectroscopic studies on the interaction of morin-Eu(III) complex with calf thymus DNA," Journal of Molecular Structure, vol. 923, no. 1-3, pp. 114-119, 2009.

[10] X. Yang, Z. Hu, S. Y. Chan et al., "Novel agents that potentially inhibit irinotecan-induced diarrhea," Current Medicinal Chemistry, vol. 12, no. 11, pp. 1343-1358, 2005.

[11] R. D. Gray and S. D. Stroupe, "Kinetics and mechanism of bilirubin binding to human serum albumin," Journal of Biological Chemistry, vol. 253, no. 12, pp. 4370-4377, 1978.

[12] F. L. Guo, B. H. Chang, and C. J. Rizzo, "An N1-hydrogen bonding model for flavin coenzyme," Bioorganic and Medicinal Chemistry Letters, vol. 12, no. 2, pp. 151-154, 2002.

[13] R. Hajian and T. G. Huat, "Electrochemical study on the interaction of irinotecan with calf thymus double stranded DNA," Chinese Journal of Chemistry, vol. 30, no. 3, pp. 738-742, 2012.

[14] Y. T. Wang, F. L. Zhao, K. A. Li, and S. Y. Tong, "Molecular spectroscopic study of DNA binding with neutral red and application to assay of nucleic acids," Analytica Chimica Acta, vol. 396, no. 1, pp. 75-81, 1999.

[15] C. Z. Huang, Y. F. Li, and P. Feng, "A spectrophotometric study on the interaction of neutral red with double-stranded DNA in large excess," Talanta, vol. 55, no. 2, pp. 321-328, 2001.

[16] Z. X. Wang, Z. L. Zhang, D. J. Liu, and S. Dong, "A temperaturedependent interaction of neutral red with calf thymus DNA," Spectrochimica Acta A, vol. 59, no. 5, pp. 949-956, 2003.

[17] H. Heli, S. Z. Bathaie, and M. F. Mousavi, "Electrochemical investigation of neutral red binding to DNA at the surface," Electrochemistry Communications, vol. 6, no. 11, pp. 1114-1118, 2004.
[18] J. B. Lepecq and C. Paoletti, "A fluorescent complex between ethidium bromide and nucleic acids. Physical-Chemical characterization," Journal of Molecular Biology, vol. 27, no. 1, pp. 87-106, 1967.

[19] V. W. F. Burns, "Fluorescence polarization characteristics of the complexes between ethidium bromide and rRNA, tRNA, and DNA," Archives of Biochemistry and Biophysics, vol. 145, no. 1, pp. 248-254, 1971.

[20] Y. Ni, S. Du, and S. Kokot, "Interaction between quercetincopper(II) complex and DNA with the use of the Neutral Red dye fluorophor probe," Analytica Chimica Acta, vol. 584, no. 1, pp. 19-27, 2007.

[21] P. Yang and C. Q. Zhou, "Study on the interaction between calcein and herring sperm DNA by spectrometry," Acta Chimica Sinica, vol. 61, no. 1, pp. 1455-1460, 2003.

[22] S. Z. Bathaie, L. Nikfarjam, R. Rahmanpour, and A. A. MoosaviMovahedi, "Spectroscopic studies of the interaction of aspirin and its important metabolite, salicylate ion, with DNA, A.T and G.C rich sequences," Spectrochimica Acta A, vol. 77, no. 5, pp. 1077-1083, 2010.

[23] M. Purcell, J. F. Neault, and H. A. Tajmir-Riahi, "Interaction of taxol with human serum albumin," Biochimica et Biophysica Acta, vol. 1478, no. 1, pp. 61-68, 2000.

[24] R. Hajian, N. Shams, and A. Parvin, "DNA-binding studies of daunorubicin in the presence of methylene blue by spectroscopy and voltammetry techniques," Chinese Journal of Chemistry, vol. 27, no. 6, pp. 1055-1060, 2009.

[25] R. Hajian and M. Zafari, "Study on the interaction of vitamin B12 with DNA by spectroscopy and electrochemical methods," Chinese Journal of Chemistry, vol. 29, no. 7, pp. 1353-1358, 2011.

[26] Mudasir, N. Yoshioka, and H. Inoue, "DNA binding of iron(II) mixed-ligand complexes containing 1,10- phenanthroline and 4,7-diphenyl-1,10-phenanthroline," Journal of Inorganic Biochemistry, vol. 77, no. 3-4, pp. 239-247, 1999.

[27] D. H. Tjahjono, T. Akutsu, N. Yoshioka, and H. Inoue, "Cationic porphyrins bearing diazolium rings: synthesis and their interaction with calf thymus DNA," Biochimica et Biophysica Acta, vol. 1472, no. 1-2, pp. 333-343, 1999.

[28] D. H. Tjahjono, T. Yamamoto, S. Ichimoto, N. Yoshioka, and H. Inoue, "Synthesis and DNA-binding properties of bisdiazoliumylporphyrins," Journal of the Chemical Society, no. 18, pp. 3077-3081, 2000.

[29] I. Haq, P. Lincoln, D. Suh, B. Norden, B. Z. Chowdhry, and J. B. Chaires, "Interaction of Delta- and Lambda$\left[\mathrm{Ru}(\text { phen })_{2} \mathrm{DPPZ}\right]^{2+}$ with DNA: a calorimetric and equilibrium binding study," Journal of the American Chemical Society, vol. 117, no. 17, pp. 4788-4796, 1995.

[30] M. T. Record, C. F. Anderson, and T. M. Lohman, "Thermodynamic analysis of ion effects on the binding and conformational equilibria of proteins and nucleic acids: the roles of ion association or release, screening, and ion effects on water activity," Quarterly Reviews of Biophysics, vol. 11, no. 2, pp. 103-178, 1978.

[31] K. Mudasir, E. T. Wahyuni, D. H. Tjahjono, N. Yoshioka, and H. Inoue, "Spectroscopic studies on the thermodynamic and thermal denaturation of the ct-DNA binding of methylene blue," Spectrochimica Acta A, vol. 77, no. 2, pp. 528-534, 2010.

[32] K. Mudasir, K. Wijaya, N. Yoshioka, and H. Inoue, "DNA binding of iron(II) complexes with 1,10-phenanthroline and 4,7diphenyl-1,10-phenanthroline: salt effect, ligand substituent 
effect, base pair specificity and binding strength," Journal of Inorganic Biochemistry, vol. 94, no. 3, pp. 263-271, 2003.

[33] J. B. Chaires, S. Satyanarayana, D. Suh, I. Fokt, T. Przewloka, and W. Priebe, "Parsing the free energy of anthracycline antibiotic binding to DNA," Biochemistry, vol. 35, no. 7, pp. 2047-2053, 1996.

[34] M. T. Record and R. S. Spolar, "Some thermodynamic principles of nonspecific and site-specific protein-DNA interactions," in Nonspecific DNA-Protein Interactions, A. Revzin, Ed., pp. 33-69, CRC Press, Boca Raton, Fla, USA, 1990.

[35] Y. N. Ni, S. Du, and S. Kokot, "Interaction between quercetincopper(II) complex and DNA with the use of the Neutral Red dye fluorophor probe," Analytica Chimica Acta, vol. 584, no. 1, pp. 19-27, 2007.

[36] C. V. Kumar, R. S. Turner, and E. H. Asuncion, "Groove binding of a styrylcyanine dye to the DNA double helix: the salt effect," Journal of Photochemistry and Photobiology A, vol. 74, no. 2-3, pp. 231-238, 1993.

[37] C. Fengling, H. Ruina, H. Guangquan et al., "Study on the interaction between aglycon of daunorubicin and calf thymus DNA by spectroscopy," Journal of Molecular Structure, vol. 1001, no. 1-3, pp. 104-110, 2011. 

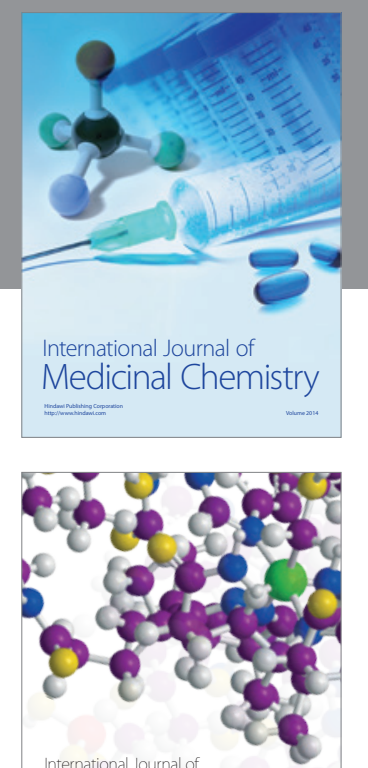

\section{Carbohydrate} Chemistry

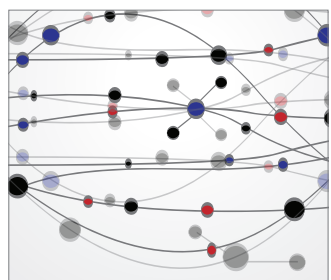

The Scientific World Journal
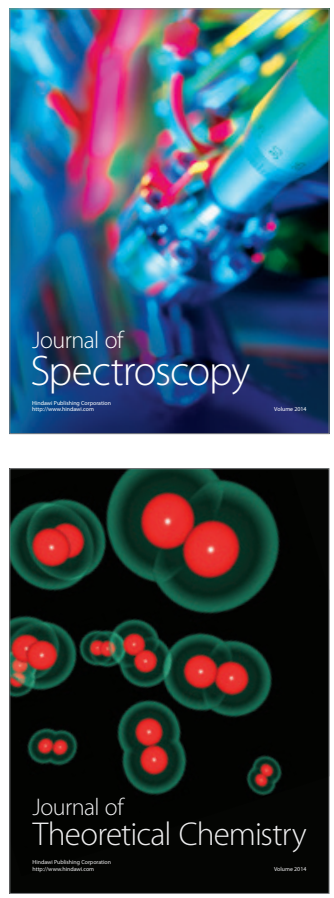
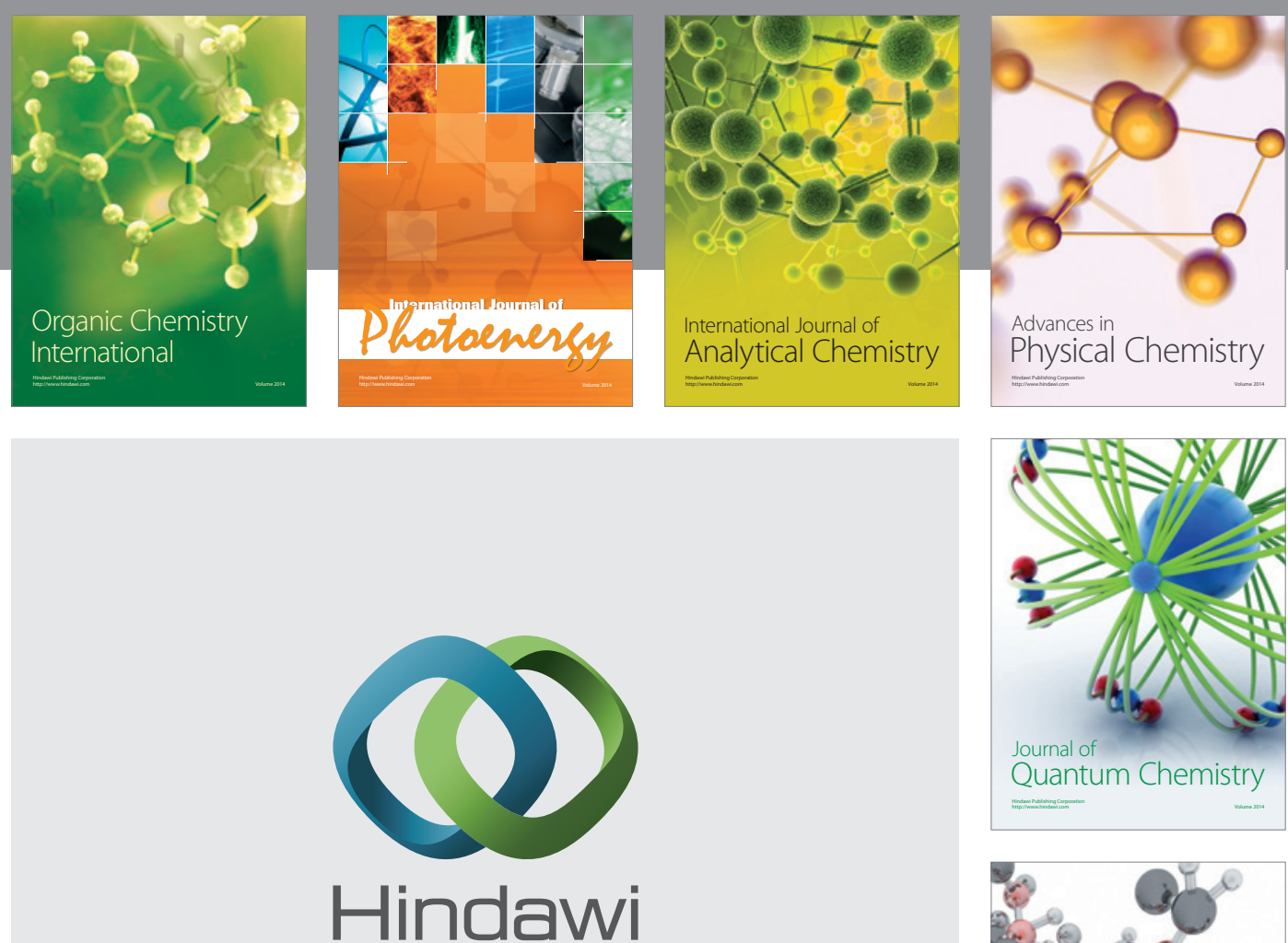

Submit your manuscripts at

http://www.hindawi.com

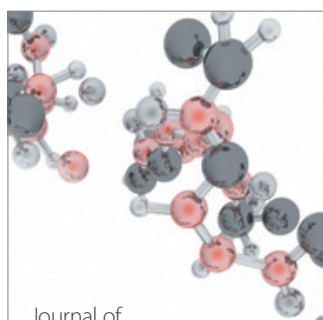

Analytical Methods

in Chemistry

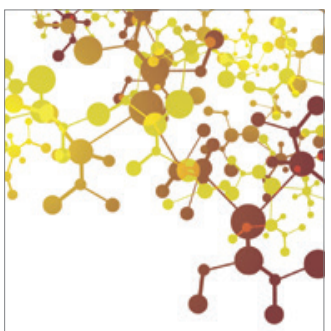

Journal of

Applied Chemistry

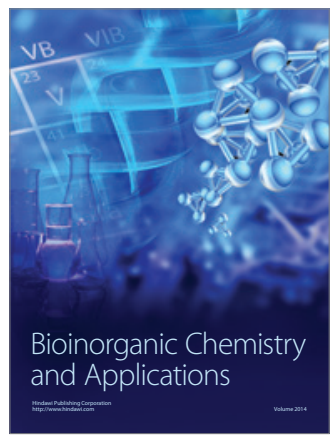

Inorganic Chemistry
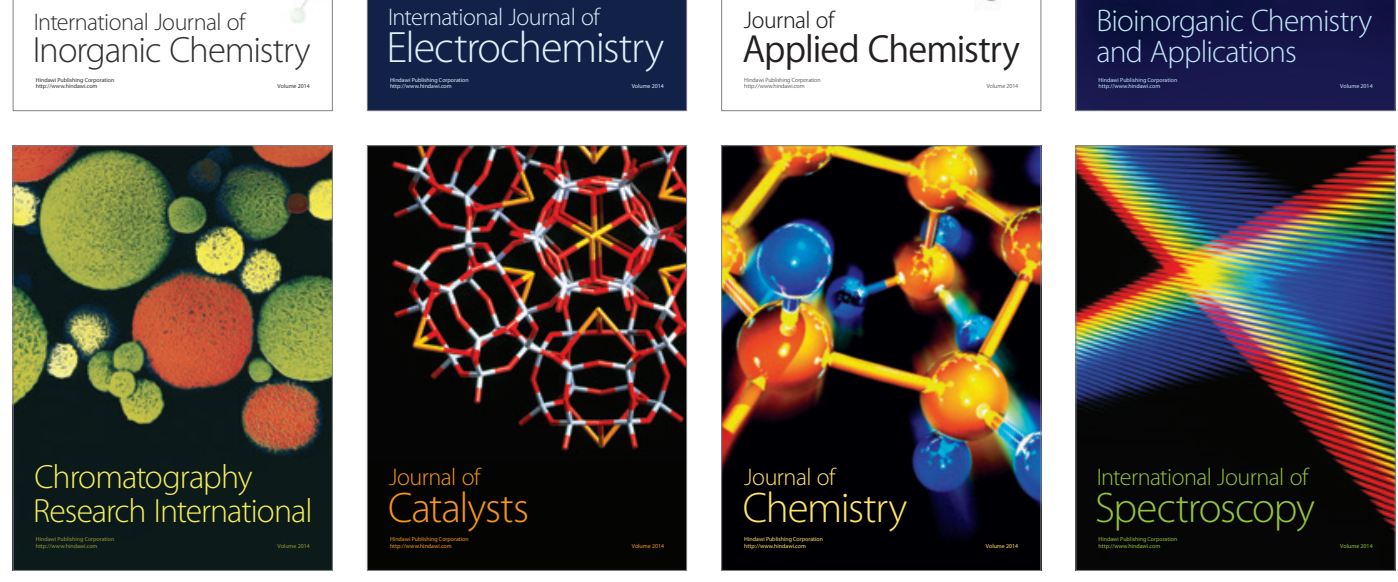